Article

\title{
The Genetic Differences and Structure of Selected Important Populations of the Endangered Taxus baccata in the Czech Republic
}

\author{
Martina Komárková *, Petr Novotný, Helena Cvrčková and Pavlína Máchová
}

Citation: Komárková, M.; Novotný, P.; Cvrčková, H.; Máchová, P. The Genetic Differences and Structure of Selected Important Populations of the Endangered Taxus baccata in the Czech Republic. Forests 2022, 13, 137. https://doi.org/10.3390/f13020137

Academic Editors: Carol A. Loopstra and Dušan Gömöry

Received: 30 November 2021

Accepted: 14 January 2022

Published: 18 January 2022

Publisher's Note: MDPI stays neutral with regard to jurisdictional claims in published maps and institutional affiliations.

Copyright: (C) 2022 by the authors. Licensee MDPI, Basel, Switzerland. This article is an open access article distributed under the terms and conditions of the Creative Commons Attribution (CC BY) license (https:// creativecommons.org/licenses/by/ $4.0 /)$.
Forestry and Game Management Research Institute, Strnady 136, 25202 Jíloviště, Czech Republic; pnovotny@vulhm.cz (P.N.); cvrckova@vulhm.cz (H.C.); machova@vulhm.cz (P.M.)

* Correspondence: komarkova@vulhm.cz

\begin{abstract}
Taxus baccata L. (common yew) is an endangered tree species in the Czech Republic. However, its natural occurrence has not been adequately protected in all areas of the country. The aim of this study is to determine whether the yew population in the newly established Mařeničky seed orchard (TS_L) enables mixing with other Czech yew populations. Using a set of nuclear microsatellites, the genetic diversity in the Lužické Mountains (TS_L) and in selected wild-provenance populations from the Czech Republic (Jílovské yews, TS_J; Březinské yews, TS_B, and yews from Moravský Karst, TS_M) was studied, as they could be donor sources for potential translocation activities. We observed that the level of genetic diversity within the four Czech yew units that were investigated was high. An analysis of the molecular variance (AMOVA) showed 7\% variation among populations, and the genetic differentiation values were low to moderate $\left(F_{\mathrm{ST}}=0.042-0.108\right)$. According to a STRUCTURE analysis, high genetic similarity was observed between the TS_L and TS_B units. Our results provide important genetic suggestions on how conservation management can be designed to maximize its success.
\end{abstract}

Keywords: endangered species conservation; genetic differentiation; genetic structure; seed orchard; SSR analysis; Taxus baccata L.

\section{Introduction}

Forests cover $33.8 \%$ of the total area of the Czech Republic [1], with a major proportion comprising Norway spruce, Scots pine, and European beech. Shaped by past human activities, most Czech forests have lost their original biodiversity, even at the tree species level. One type of tree that previously had a higher abundance is undoubtedly Taxus baccata $\mathrm{L}$. (common yew), a long-lived dioecious species that is well known for its Taxol content [2], which is significant for the treatment of cancer from a pharmaceutical point of view. In the Czech Republic, there are a number of isolated localities (almost obligatorily declared as specially protected areas) that contain a total of about 13,000 yews, but it is mostly in limited numbers. The largest populations in Bohemia are the Křivoklátsko Protected Landscape Area (PLA), which has approx. 3000 individuals, the Vltava River Region (approx. 2000), the foothills of the Šumava Mountains (hundreds), and the Lužické (Lusatian) Mountains PLA (dozens); in Moravia, the largest populations are in the Moravian Karst PLA (approx. 3000) and the Svitavy Region (several hundred). The species is also used for ornamental gardening in cities, gardens, and parks. Originally, it was much more abundant, as evidenced by a number of toponyms. Today's small localities thus represent fragments of the original distribution [3]. Due to its slow growth rate and shorter height, T. baccata is often outcompeted by Abies, Fagus, and Picea [4] and rarely occurs in large numbers. It is a specially protected plant species according to valid national Czech legislation (Act no. 114/1992 Coll., Decree no. 395/1992 Coll.) and is classified as being a "highly endangered" species. However, in the Red List of Vascular Plants of the Czech Republic [5], the common 
yew is classified as vulnerable, and in the Red Book of Tree Species of the Czech Republic [3], it is classified as being a near-threatened species. Due to human pressure, natural yew populations have been reduced across all of Europe [6]. The decline and reduction in these populations was mainly caused by a combination of targeted logging, a variety of methods that have been used for forestry management (sudden changes in light conditions), and pastoralism (eradication due to horse poisoning). At present, almost all seedlings resulting from natural regeneration are decimated by high numbers of even-toed ungulate hunting populations; thus, it is only the longevity of this tree species that contributes to the population stability [3]. However, climate, dioecy, and excessive shade are also important causal factors resulting in the reduction of natural yew populations $[4,7,8]$. Since existing spatial structures together with ongoing fragmentation limit the gene flow, the effective population size is reduced, resulting in inbreeding [9]. The currently fragmented distribution of yews might cause a further reduction in species abundance. Thus, urgent conservation activity is required because ensuring genetic variability may be essential for the survival of endangered populations [2].

To preserve the rest of the declining T. baccata population in the Lužické Mountains PLA (northern Bohemia) from extinction in the long term, augmentation plantings are being implemented, but thus far, they have only come from a limited number of parent trees $[10,11]$. To eliminate this inappropriate solution, the seed orchard Mařeničky (SO, cultivated unit), which contains concentrated important natural yew gene sources from the Lužické Mountains occurrences, was established in 2016 [12,13]. Of the 18 (Figure 1) detected occurrences (mostly individual trees or their smaller groups), only 15 can be considered autochthonous. However, the vast majority of the residual yew population in the Lužické Mountains has only been preserved in one larger locality (No. 3 in Figure 1), which contains dozens of surviving individuals. Therefore, SO Mařeničky simultaneously plays a parallel function of selecting the most important local native yews and providing a clone archive. It currently contains 62 clones of selected individuals from all of the 15 autochthonous occurrences; thus, it represents the entire preserved population of the Lužické Mountains well. Since the SO still has unused areas, supplementing this area with clones from the geographically closest occurrences of yew (i.e., Březinské yews in approx. $40 \mathrm{~km}$ distance and Jílovské yews, approx. $50 \mathrm{~km}$ ) in order to increase the genetic diversity of the produced offspring was considered. The two closest sites are located in other provenance regions called "Nature Forest Areas", 41 of which exist in the Czech Republic. However, due to the possibility of conducting molecular genetic analyses in order to avoid the inappropriate mixing of sub-populations, it was necessary to answer the following questions: (1) Is the degree of genetic diversity of the Lužické yews population sufficient? (2) Is the admixture of the selected individuals from the geographically closest populations of the Březinské yews (TS_B) or Jílovské yews (TS_J) genetically suitable? DNA analysis was conducted to assess the level of genetic diversity, heterozygosity, and other genetic characteristics of yew samples and to prevent inbred depression, bottleneck effects, and genetic drift [10].

One of the most powerful and widely used tools for the analysis of genetic variation and forestry population structures is simple sequence repeats (SSRs, or microsatellites) [11,14-16]. Microsatellites are tandem repeats of short motifs that are 1 to $10 \mathrm{bp}$ in length and that usually have a simple repeated sequence that consists of two, three or four nucleotides [17]. Molecular DNA markers can detect significant differences at the DNA level that arise from deletion, duplication, inversion, and/or insertion in the chromosomes. Microsatellites are only located near or are linked to the genes controlling traits; thus, they do not affect the phenotypes of the traits of interest. These markers are inherited both in dominant and codominant patterns and are not affected by environmental factors or the developmental stage of the plant [18]. Microsatellites generate highly informative content since they are polymorphic, multi-allelic, and reproducible [19]. 


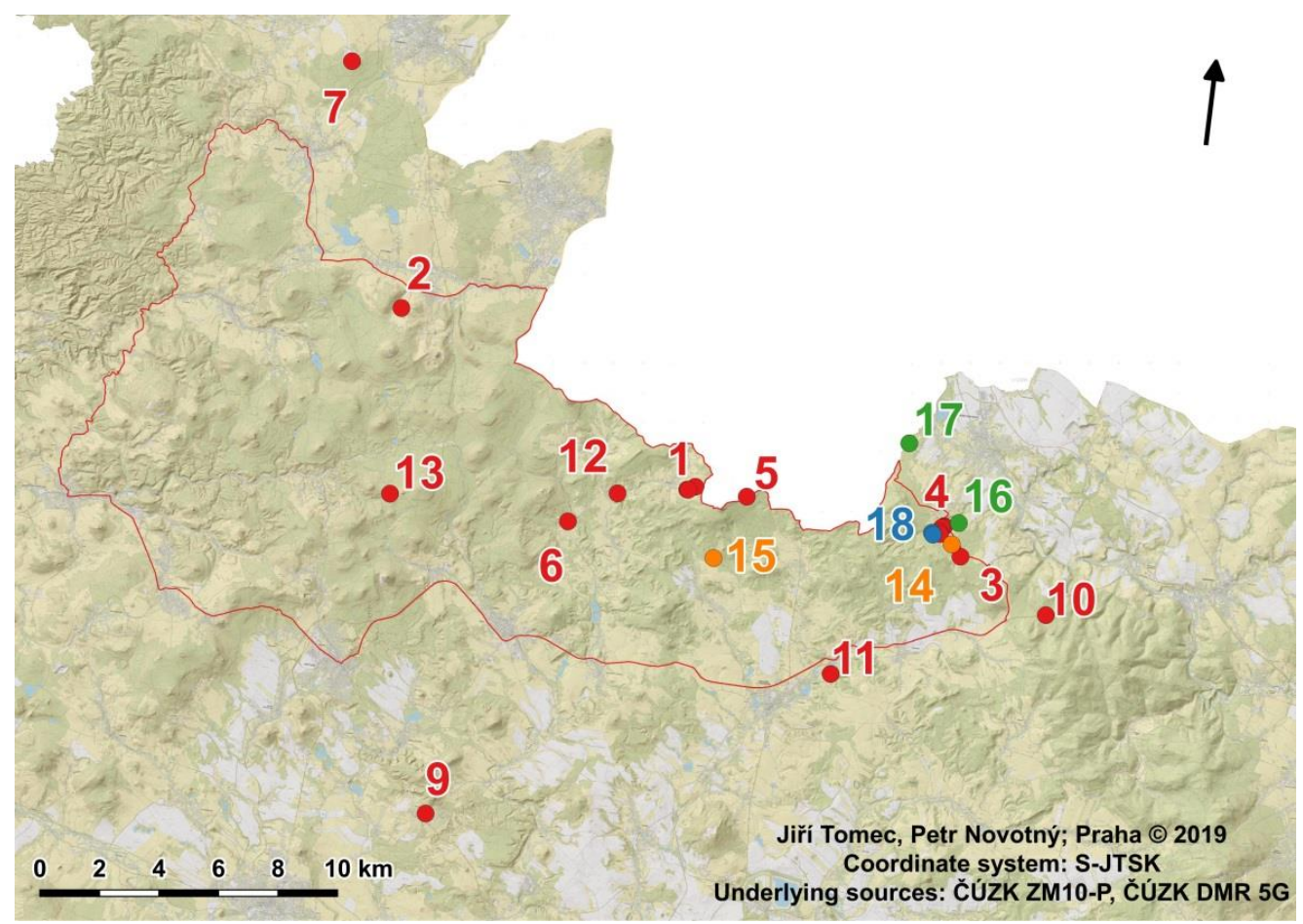

Figure 1. Localities of inventoried yew occurrences in the Lusatian Mountains (red border of the PLA); colour coding reflects the time when the sites were inventoried: until 2005: red, 2006-2010: orange, 2011-2015: green, 2016-2020: blue (QGIS 3.8.3 Zanzibar, background ZM10-P a DMR 5G).

Considering the limited knowledge about the genetic structure of yew, it was necessary to provide detailed investigations and research to obtain comprehensive genetic information and to develop conservation guidance based on this genetic perspective.

In the present study, we used SSRs to examine the genetic characteristics of four natural common yew populations in the Czech Republic. The specific aims of our study were to determine the level of genetic diversity and the genetic structure of yew populations and to provide a practical conservation strategy and effort.

\section{Materials and Methods}

\subsection{Origin of Populations and Their Sampling}

In this study, three natural T. baccata populations (Jílovské yews, TS_J; Březinské yews, TS_B, and yews from the Moravský Kras, TS_M) comprising a total of 125 individuals were used to compare their genetic diversity with the population in Lužické Mountains, which is concentrated in SO Mařeničky (TS_L). The yew population from the Protected Landscape Area Moravský Kras (Moravian Karst), TS_M, was included in the comparative analyses, as it is geographically quite distant, and according to the authors of [20], it should be genetically different from the three subpopulations from northern Bohemia. All of the populations are located in the Czech Republic (Table 1; Figure 2). In total, 165 individuals were subjected to microsatellite analysis. Where the number of yews at individual sites allowed it, a distance of at least $100 \mathrm{~m}$ was maintained between the donor individuals for the needle samples used for DNA analysis. 
Table 1. The location, source population size, code, longitude/latitude, and number of the Taxus baccata individuals analysed (PLA, protected landscape area; NM, natural monument; NNR, national nature reserve).

\begin{tabular}{|c|c|c|c|c|c|}
\hline & Location & $\begin{array}{l}\text { Source Population Size } \\
\text { (Trees More Than } 1 \mathrm{~m} \text { ) }\end{array}$ & $\begin{array}{c}\text { Code of } \\
\text { Population }\end{array}$ & $\begin{array}{c}\text { Geographic } \\
\text { Coordinates } \\
\text { (WGS84) }\end{array}$ & $\begin{array}{l}\text { Individuals } \\
\text { Analysed }\end{array}$ \\
\hline \multirow[t]{2}{*}{$\begin{array}{l}\text { Seed Orchard } \\
\text { Mařeničky }\end{array}$} & $\begin{array}{l}\text { PLA Lužické } \\
\text { (Lusatian) } \\
\text { Mountains }\end{array}$ & 150 & TS_L & $\begin{array}{l}50^{\circ} 49^{\prime} 4.49776^{\prime \prime} \mathrm{N} \\
14^{\circ} 50^{\prime} 58.00724^{\prime \prime} \mathrm{E}\end{array}$ & 40 \\
\hline & NM Jílovské yews & 385 & TS_J & $\begin{array}{c}50^{\circ} 45^{\prime} 21.87152^{\prime \prime} \mathrm{N} \\
14^{\circ} 5^{\prime} 52.63455^{\prime \prime} \mathrm{E}\end{array}$ & 40 \\
\hline \multirow[t]{2}{*}{$\begin{array}{c}\text { Natural } \\
\text { Populations }\end{array}$} & $\begin{array}{c}\text { NNR Březinské } \\
\text { yews }\end{array}$ & 176 & TS_B & $\begin{array}{l}50^{\circ} 45^{\prime} 13.11222^{\prime \prime} \mathrm{N} \\
14^{\circ} 15^{\prime} 1.90919^{\prime \prime} \mathrm{E}\end{array}$ & 40 \\
\hline & $\begin{array}{c}\text { PLA Moravský } \\
\text { Kras (Moravian } \\
\text { Karst) }\end{array}$ & app. 2500 & TS_M & $\begin{array}{c}49^{\circ} 20^{\prime} 54.11839^{\prime \prime} \mathrm{N} \\
16^{\circ} 43^{\prime} 0.07176^{\prime \prime} \mathrm{E}\end{array}$ & 45 \\
\hline
\end{tabular}

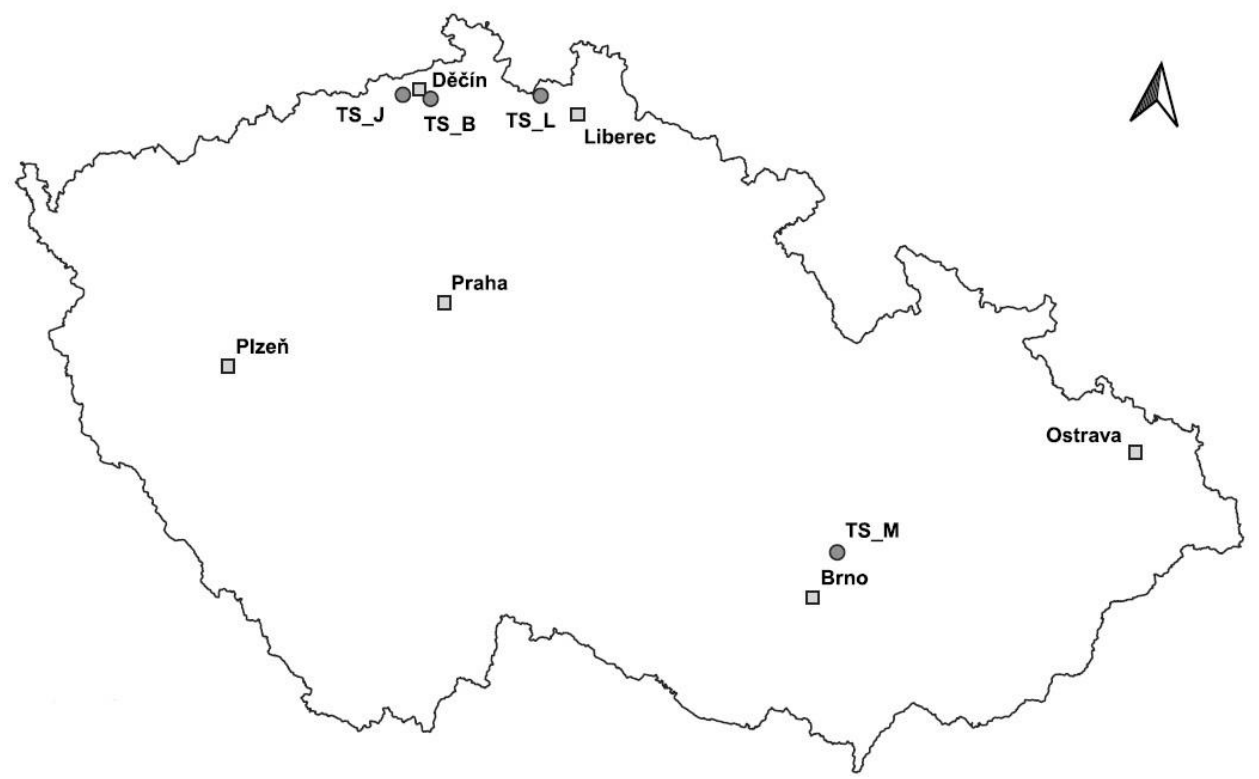

Figure 2. Map of the geographical locations of the four Taxus baccata populations included in this study. The population codes are given in Table 1.

\subsection{DNA Extraction and Microsatellite Genotyping}

Genomic DNA was isolated from $20 \mathrm{mg}$ of young, lyophilized T. baccata needles from each tree with the DNeasy ${ }^{\circledR}$ Plant Mini Kit (Qiagen, Germantown, MD, USA), according to the manufacturer's instructions. The concentration and purity of the extracted DNA were estimated spectrophotometrically using a NanoPhotometer (Implen, München, Germany). DNA was stored at $4{ }^{\circ} \mathrm{C}$.

The entire set of 165 T. baccata individuals was scored for a total of seven SSRs, which were previously described by [22,23]. The following dinucleotide motifs, whose PCR products provided clear and reproducible patterns, were used: TAX23, TAX26, TAX36, TAX86, TAX92, TS09, and TAX362. Details of the studied SSRs are in Table 2. Polymerase chain reactions (PCRs) were performed in two multiplexes from the point of view of the targeted allele sizes in a total volume of $15 \mu \mathrm{L}$, which was composed of $1 \mu \mathrm{L}$ DNA template (10-50 ng), a $1.5 \mu \mathrm{L}$ PCR buffer (Mg-free), a $0.2 \mathrm{mM}$ dNTPs mixture (Takara Bio Inc., Otsu, Shiga, Japan), $2 \mathrm{mM} \mathrm{MgCl}_{2}, 0.37 \mathrm{U}$ of Platinum ${ }^{\circledR}$ Taq DNA polymerase (Invitrogen, 
Carlsbad, CA, USA), a primer mix, and RNase-Free water for molecular biology (SigmaAldrich, St. Louis, MO, USA). The primer concentrations of the loci TAX26 and TAX92 were $0.1 \mu \mathrm{M}$, and those of the loci TAX23, TAX36, and TAX86 were $0.2 \mu \mathrm{M}$. The PCR conditions for both multiplexes were as follows: an initial denaturation step at $94{ }^{\circ} \mathrm{C}$ for $5 \mathrm{~min}$ followed by 35 cycles at $94{ }^{\circ} \mathrm{C}$ for $30 \mathrm{~s}, 40 \mathrm{~s}$ at $58^{\circ} \mathrm{C}$ (primer annealing), and $40 \mathrm{~s}$ at $72{ }^{\circ} \mathrm{C}$, and a final extension at $72{ }^{\circ} \mathrm{C}$ for $20 \mathrm{~min}$. For the locus TAX362, the primer concentration was $0.2 \mu \mathrm{M}$, the primer annealing temperature was $61^{\circ} \mathrm{C}$, and the PCR conditions were the same as those for the primers above. The fluorescently labelled PCR products and an internal size standard (GeneScan ${ }^{\mathrm{TM}} 600$ LIZ $^{\circledR}$, Applied Biosystems, Foster City, CA, USA) were mixed with formamide (Hi-Di ${ }^{\mathrm{TM}}$ Formamide, Foster City, CA, USA, Applied Biosystems). After denaturation at $94{ }^{\circ} \mathrm{C}$ for $3 \mathrm{~min}$ and immediate chilling on ice, the products were analysed using a genetic analyser 3500 (Applied Biosystems, Foster City, CA, USA). The alleles were identified based on their size using GeneMapper ${ }^{\circledR} 4.1$ software, which was provided by Applied Biosystems. Allele binning was performed manually after plotting the fragment size distribution for each locus [24].

Table 2. Locus, repeat structure, allele size, PCR conditions and fluorescent dyes.

\begin{tabular}{cccccc}
\hline & SSR & $\begin{array}{c}\text { Repeat } \\
\text { Structure }\end{array}$ & $\begin{array}{c}\text { Allele Size } \\
\mathbf{( b p )}\end{array}$ & $\begin{array}{c}\text { PCR } \\
\text { Conditions }\end{array}$ & $\begin{array}{c}\text { Fluorescent } \\
\text { Dye }\end{array}$ \\
\hline \multirow{4}{*}{ Multiplex 1 } & TAX23 & $(\mathrm{GT})_{21}$ & $153-183$ & $58^{\circ} \mathrm{C} / 40 \mathrm{~s}$ & PET \\
& TAX26 & $(\mathrm{GT})_{30}$ & $208-284$ & $58^{\circ} \mathrm{C} / 40 \mathrm{~s}$ & NED \\
& TAX36 & $(\mathrm{GT})_{25}$ & $126-262$ & $58^{\circ} \mathrm{C} / 40 \mathrm{~s}$ & VIC \\
& TAX86 & $(\mathrm{GT})_{34}$ & $152-304$ & $58^{\circ} \mathrm{C} / 40 \mathrm{~s}$ & FAM \\
\hline \multirow{2}{*}{ Multiplex 2 } & TAX92 & $(\mathrm{GT})_{24}$ & $160-280$ & $58^{\circ} \mathrm{C} / 40 \mathrm{~s}$ & NED \\
& TS09 & $(\mathrm{TC})_{12}$ & $217-247$ & $58^{\circ} \mathrm{C} / 40 \mathrm{~s}$ & VIC \\
\hline & TAX362 & $(\mathrm{CA})_{19}$ & $85-119$ & $61^{\circ} \mathrm{C} / 40 \mathrm{~s}$ & FAM \\
\hline
\end{tabular}

\subsection{Genetic Diversity and Differentiation in Tested Populations}

The program FreeNA was used to estimate pairwise $F_{\mathrm{ST}}$ values with and without the ENA ("excluding null alleles") correction for null alleles [25].

The majority of the genetic diversity parameters-the number of alleles, Shannon's information index, observed heterozygosity, expected heterozygosity, fixation index $(F)$, Nei's genetic distance, and AMOVA-were calculated using the statistical program GenAlEx v. 6.501 [26]. AMOVA was used to assess the molecular variance within and between populations at 999 permutations. Deviations from the Hardy-Weinberg equilibrium (HWE) for the studied loci were assessed using CERVUS 3.0.7 with Bonferroni correction to evaluate the deviation significance. Allelic richness based on the minimum sample size was computed in FSTAT.

The software STRUCTURE v. 2.3.4 [27-29] was used with the Bayesian clustering approach to determine the genotypic structure of the tested populations. For genetic population structure analysis, we used the LockPrior model, which considers that the prior distribution of cluster assignments can vary among populations. When the genetic data are not informative, the use of this approach is recommended to help detect the population structure [30]. Analysis was performed with the following parameters: the number of clusters $(K)=1-10$ with 10 independent runs for each $K$; ancestry model $=$ admixture model; and allele frequency model $=$ correlated allele frequencies. We used a of burn-in period length of 10,000 and 100,000 Markov chain Monte Carlo (MCMC) repeats after the burn-in period. The best estimate of the $K$ values was calculated using the web-based STRUCTURE HARVESTER program v. 0.6.94 [31]. Once the most likely $K$ value was determined, the run with higher posterior probability and lower variance was chosen to interpret the results. 


\section{Results}

\subsection{Genetic Diversity}

The genetic diversity parameters for all seven microsatellite loci are shown in Table 3. The average number of different alleles per locus ranged from 6.5 (TAX23) to 19.3 (TAX92). On average, allelic richness was 14.44, based on the minimum sample size of 38 diploid individuals. Shannon's information index, which was calculated for allelic and genetic diversity, ranged from 1.42 (TAX23) to 2.42 (TAX92). The observed heterozygosity $\left(H_{\mathrm{o}}\right)$ was generally lower than the expected heterozygosity $\left(H_{\mathrm{e}}\right)$. All of the microsatellites presented high levels of genetic diversity $\left(H_{\mathrm{e}}\right.$; from 0.69 at locus TAX23 to 0.86 at loci TAX36 and TAX92). The fixation index values varied from 0.10 (TAX23) to 0.54 (TAX86). The average frequency of the null alleles at the seven markers over the populations ranged from 0.03 to 0.25 , with a mean of 0.166 across all markers (Table 3 ).

Table 3. Characteristics of selected nuclear microsatellite loci across the four investigated Taxus baccata populations. $N_{\mathrm{a}}$, average number of different alleles; $A_{\mathrm{r}}$, allelic richness after correcting for a sample size of 38 diploid individuals; $I$, Shannon's information index; $H_{\mathrm{o}}$, observed heterozygosity; $H_{\mathrm{e}}$, expected heterozygosity; $F$, significant deviation of the fixation index from the Hardy-Weinberg equilibrium $\left.(\mathrm{HWE}){ }^{* * *} p<0.001\right) ; F_{\text {null}}$, null allele frequencies using the FreeNA programme.

\begin{tabular}{cccccccc}
\hline Locus & $\boldsymbol{N}_{\mathbf{a}}$ & $\boldsymbol{A}_{\mathbf{r}}$ & $\boldsymbol{I}$ & $\boldsymbol{H}_{\mathbf{o}}$ & $\boldsymbol{H}_{\mathbf{e}}$ & $\boldsymbol{F}$ & $\boldsymbol{F}_{\text {null }}$ \\
\hline TAX23 & 6.50 & 8.19 & 1.42 & 0.63 & 0.69 & $0.10^{* * * *}$ & 0.03 \\
TAX26 & 13.0 & 17.26 & 1.83 & 0.49 & 0.75 & $0.34^{* * *}$ \\
TAX36 & 14.5 & 19.43 & 2.23 & 0.63 & 0.86 & $0.27^{* * *}$ & 0.13 \\
TAX86 & 13.3 & 16.53 & 2.17 & 0.39 & 0.85 & $0.54^{* * *}$ & 0.25 \\
TAX92 & 19.3 & 25.75 & 2.42 & 0.42 & 0.86 & $0.51^{* * *}$ & 0.23 \\
TS09 & 9.00 & 12.60 & 1.76 & 0.43 & 0.78 & $0.45^{* * *}$ & 0.20 \\
TAX362 & 9.25 & 11.30 & 1.66 & 0.42 & 0.73 & $0.44^{* * *}$ & 0.19 \\
\hline
\end{tabular}

From the 165 individuals assayed, a total of 339 alleles were identified. The number of alleles per locus ranged from 10 (TAX23) to 39 (TAX92). The average number of different alleles $\left(N_{\mathrm{a}}\right)$ within the populations was from 10.1 (pops TS_J and TS_B) to 17.0 (pop TS_M), with a mean of 12.38 (Table 4$)$. The mean number of effective alleles $\left(N_{\mathrm{e}}\right)$ within the populations ranged from 4.62 (TS_J) to 7.99 (TS_M). The mean population genetic diversity values according to Shannon's information index (I) ranged from 1.74 (TS_J) to 2.30 (TS_M). All of the units had private alleles, with the highest number (four) of private alleles being found in population TS_M, where one allele always appeared at the loci TAX26, TAX36, TAX92, and TAX362. The mean observed heterozygosity was lower than the expected heterozygosity across the loci for each population. The mean observed heterozygosity $\left(H_{\mathrm{o}}\right)$ ranged from 0.42 (TS_B) to 0.57 (TS_M), and the mean expected heterozygosity ranged from 0.76 (TS_J) to 0.84 (TS_M).

Table 4. Parameters used to estimate the genetic structure of Taxus baccata populations. $N_{a}$, number of different alleles; $N_{\mathrm{e}}$, number of effective alleles; I, Shannon's information index; Priv. alleles, number of private alleles; $H_{\mathrm{o}}$, observed heterozygosity; $H_{\mathrm{e}}$, expected heterozygosity. The population codes are given in Table 1.

\begin{tabular}{ccccccc}
\hline Population & $\boldsymbol{N}_{\mathbf{a}}$ & $\boldsymbol{N}_{\mathbf{e}}$ & $\boldsymbol{I}$ & Priv. Alleles & $\boldsymbol{H}_{\mathbf{o}}$ & $\boldsymbol{H}_{\mathbf{e}}$ \\
\hline TS_L & 12.3 & 5.81 & 1.96 & 2.86 & 0.44 & 0.80 \\
TS_J & 10.1 & 4.62 & 1.74 & 1.71 & 0.51 & 0.76 \\
TS_B & 10.1 & 5.00 & 1.78 & 1.71 & 0.42 & 0.77 \\
TS_M & 17.0 & 7.99 & 2.30 & 4.57 & 0.57 & 0.84 \\
\hline
\end{tabular}

The genetic distances between the populations were calculated based on Nei's standard genetic distance [32]. The longest Nei's genetic distance (0.595) appeared between the TS_J and TS_B units and between the TS_J and TS_L units (0.572). 


\subsection{Genetic Differentiation}

The program FreeNa $[25,33]$ was used to calculate the null allele frequencies and the global $F_{\mathrm{ST}}$ values across all of the loci. The $F_{\mathrm{ST}}$ values (Table 5) were similar regardless of whether the null alleles were taken into account or not $(0.060$ vs. 0.068 across loci considering all populations), suggesting that the effect of null alleles on the genetic structure of the populations is likely negligible.

Table 5. Genetic differentiation between populations of T. baccata based on $F_{\mathrm{ST}}$ with and without ENA correction for null alleles. The population codes are given in Table 1.

\begin{tabular}{cccc}
\hline & \multicolumn{2}{c}{$\boldsymbol{F}_{\text {ST }}$ Using ENA Correction. } & \\
\hline & TS_B & TS_M & TS_J \\
\hline TS_M & 0.034 & & \\
TS_J & 0.096 & 0.058 & 0.087 \\
TS_L & 0.045 & 0.038 & \\
\hline \multicolumn{5}{c}{ F } & TS without Using ENA & Correction. & TS_J \\
\hline TS_M & TS_B & & \\
TS_J & 0.042 & 0.062 & 0.097 \\
TS_L & 0.108 & 0.048 & \\
\hline
\end{tabular}

The pairwise $F_{\mathrm{ST}}$ matrix (Table 5) showed low and moderate levels of genetic differentiation among the four tested populations $(0.042-0.108)$. According to Wright [34], $F_{\mathrm{ST}}$ values higher than 0.15 show high genetic differentiation. The highest values of differentiation were between the TS_J and TS_B (0.108) units and between the TS_J and TS_L (0.097) units, whereas the smallest differentiation value was between TS_B and TS_M (0.042). The overall $F_{\mathrm{ST}}\left(F_{\mathrm{ST}}=0.067\right)$ demonstrated significant $(p<0.001)$ genetic variation among the four populations.

Analysis of molecular variance (AMOVA) was used to determine the genetic variation among and within the populations. The analysis indicated that there was only $7 \%$ genetic variation among the populations and $93 \%$ genetic variation within the populations (Table 6). The $F$-statistics on all three groups were found to be highly significant $(p<0.001)$. The result was consistent with that of $F_{\mathrm{ST}}$, implying that the genetic differentiation of $T$. baccata mainly existed within populations.

Table 6. Analysis of molecular variance (AMOVA) based on seven SSR markers for Taxus baccata. df, degrees of freedom; SS, sum of squares.

\begin{tabular}{ccccc}
\hline Source of Variation & df & SS & $\begin{array}{c}\text { Variance } \\
\text { Components }\end{array}$ & \% Variation \\
\hline Among populations & 3 & 61.71 & 0.22 & $7^{*}$ \\
Within populations & 326 & 914.66 & 2.81 & $93 *$ \\
\hline$p<0.001$. & & & &
\end{tabular}

\subsection{Genetic Structure of the Populations}

Analysis of the entire dataset using STRUCTURE and Structure Harvester suggested that $K=2$ was the most relevant number of clusters (Figure 3 ). The $K$ values were decreased from $K=2$ to 10 in general but slightly increased at $K=4$. According to the software documentation [30], $K=4$ was also chosen because the four clusters exhibited strong assignments with the tested populations (Figure $4 \mathrm{~b}$ ). Different colours were used to indicate the proportion of cluster membership in each individual. At $K=2$, the first cluster (red) had a significant proportion that was greater than the proportion determined in the TS_B and TS_L populations and smaller than the proportion determined the TS_M population. The second cluster (green) had a larger proportion in the TS_J and a smaller one in the TS_M 
(Figure 4a). At $K=4$, all four subpopulations exhibited significant differences. The TS_B, TS_M, and TS_J populations remained as a fixed cluster, whereas the TS_L unit showed a smaller population genetic structure, with the number of individuals assigned to the cluster belonging to the TS_M population (Figure $4 \mathrm{~b}$ ).

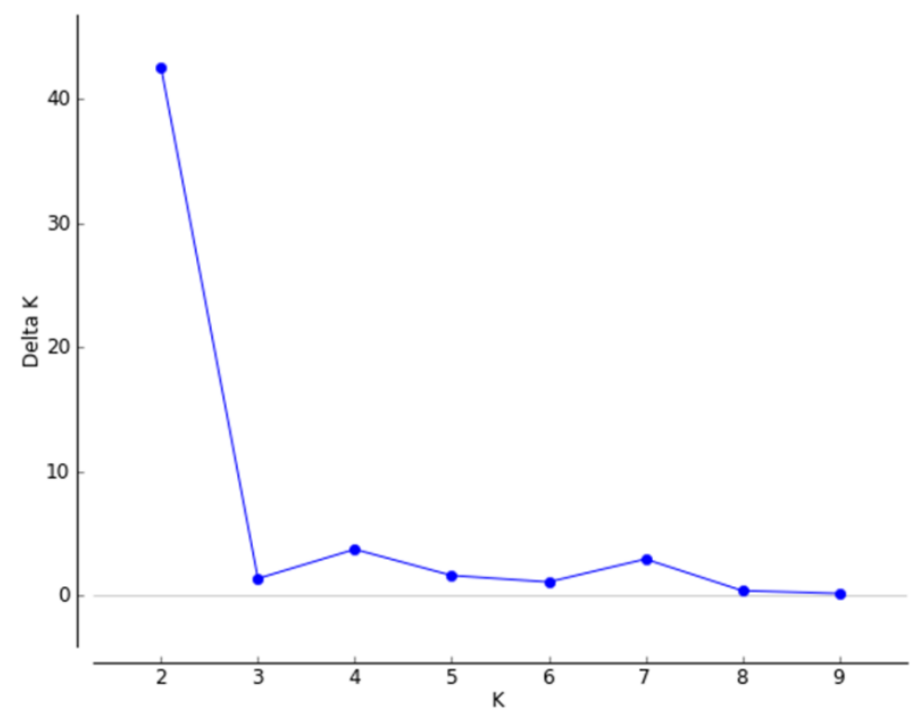

Figure 3. Delta $K$ values for the tested genetic groups $K=1$ to 10 in the program STRUCTURE based on seven SSR markers from four populations of T. baccata.

(a)

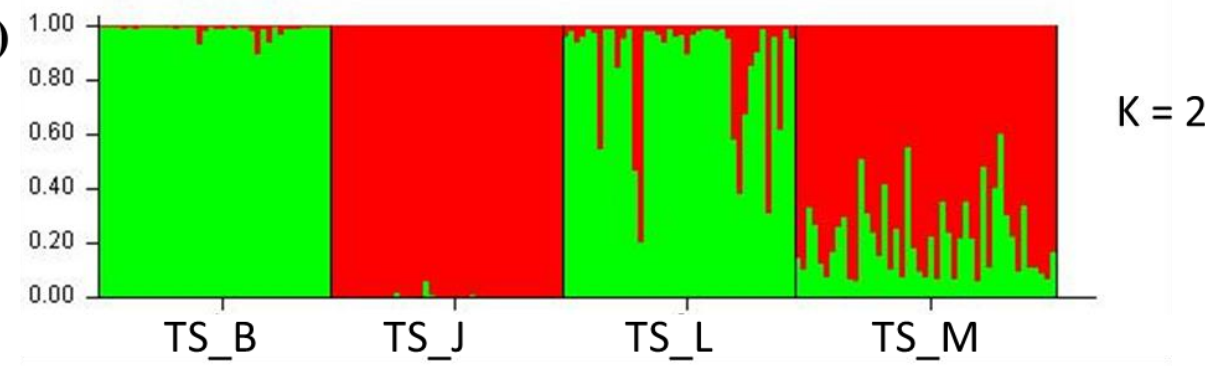

(b)

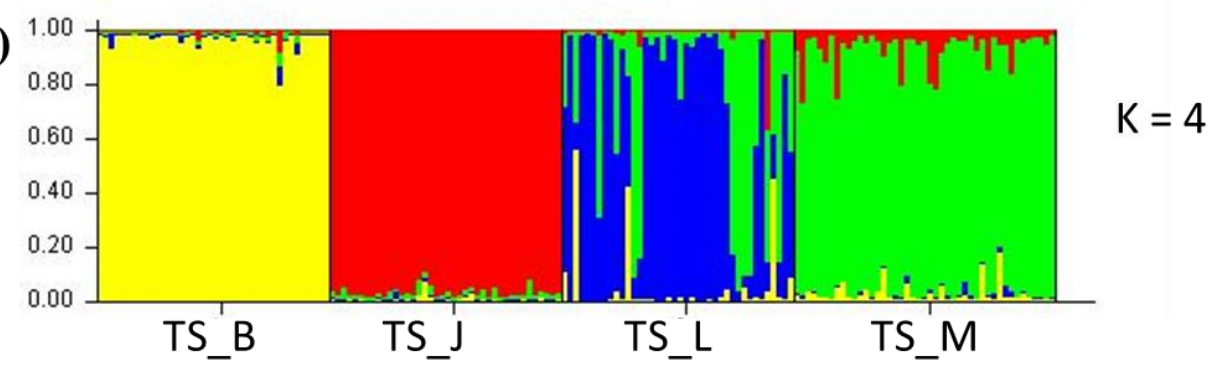

Figure 4. Analysis of the Taxus baccata populations using the STRUCTURE HARVESTER WEB version 0.6.94 (30). (a) Genetic structure assuming $K=2$; (b) genetic structure assuming $K=4$. Each individual is represented by a vertical bar broken into differently coloured genetic clusters with a length proportional to the probability of assignment to each cluster. Populations are separated by black bars and are identified at the bottom.

\section{Discussion}

\subsection{Genetic Diversity}

Genetic diversity provides useful information about history and adaptive potential and is a basis for the phylogeny and classification of taxa [35]. It is deeply influenced by the life cycle, the breeding system, the seed and pollen dispersal mechanism, the reproduction 
patterns, the geographical range size, and gene flow [36]. In T. baccata, gene dispersal may be a limiting factor for the adaptability of the species [37].

Analyses of molecular markers, such as microsatellites, are widely used to reveal the genetic diversity of many different forest species (e.g., [11,12,38,39]). The aim of our study was to determine the genetic parameters of selected T. baccata units grown in the Czech Republic to design appropriate conservation management approaches. A total of seven polymorphic microsatellite markers were successfully amplified in all of the individuals from four different populations. According to the current literature, our chosen SSR markers are the most widely used markers for genotyping T. baccata. For each locus, we detected a lack of heterozygotes over all of the tested populations compared to the Hardy-Weinberg expectations (mean $H_{\mathrm{o}}=0.487 ; H_{\mathrm{e}}=0.789$ ). Similar to our results, the authors of [22] also showed a substantial deficiency of heterozygotes in T. baccata loci that were tested in Poland. The authors of [40] used five of the SSR markers that we used (TAX23, TAX26, TAX36, TAX86, and TAX92) and showed similar values in terms of the mean $H_{\mathrm{e}}(0.82)$ and mean null allele frequency $(0.118)$ for those markers. Regarding allelic richness in our study, $A_{\mathrm{r}}$ was higher (mean $A_{r}=17.42$ ) than the levels described by authors of [40] (mean $A_{\mathrm{r}}=5.91$ ), which might indicate higher allelic diversity. Similar to our study, the authors of [22] found the smallest number of alleles in the locus TAX23 (6 alleles) and the highest number of alleles in the locus TAX92 (28 alleles). Moreover, they described almost identical mean $H_{\mathrm{e}}(0.795)$ and $H_{\mathrm{o}}(0.403)$ values for six of the SSR markers that we used (TAX23, TAX26, TAX36, TAX86, TAX92, and TS09).

Based on the SSR analysis, a moderate to high level of genetic diversity was detected among the four tested T. baccata populations concerning the expected (mean $H_{\mathrm{e}}=0.793$ ) and observed (mean $H_{\mathrm{o}}=0.485$ ) heterozygosity. Our observed and expected heterozygosity values were quite consistent with those reported for T. baccata populations from Poland [22], Spain [40], and Britain [41]. In agreement with our results, [42] also found close heterozygosity values $\left(H_{\mathrm{e}}=0.785 ; H_{\mathrm{O}}=0.446\right)$ in four populations of $T$. baccata grown in the Czech Republic. Similarly, the authors of [43] investigated the genetic diversity of T. baccata in four Polish populations that are located close to the border with the Czech Republic. As expected, these Polish populations showed $H_{\mathrm{e}}(0.791)$ and $H_{\mathrm{o}}(0.537)$ values that were close to the values that were obtained in our results. The deficiency of heterozygotes in T. baccata could be explained as a consequence of high amounts of inbreeding. At the population level, the TS_M population had the highest genetic diversity $\left(H_{\mathrm{e}}=0.84\right)$ out of the four T. baccata populations, which corresponds to the source population size (Table 1). However, the level of genetic diversity in all of the tested populations of T. baccata are high compared with the reference values for widespread plants $\left(H_{\mathrm{e}}=0.62\right.$; [44]).

\subsection{Genetic Differentiation and Genetic Structure}

Similar to the studies from Spain [40,45] and Poland [43], higher genetic variation was observed within the tested populations of T. baccata (Table 6). Moreover, despite dioecy, the $F>0.1$ also suggests mating with relatives and structuring within populations.

In the present investigation, a low to moderate level of genetic differentiation was found among the tested $T$. baccata units (mean $F_{\mathrm{ST}}=0.068$ ). These results are consistent, for example, with the research on British populations of T. baccata [41]. According to the authors of [42], both the geography and climate impact of quaternary glaciations have played a role in shaping the genetic structure of T. baccata. They found that yew colonized Europe from eastern territories towards the west and that European yews diverged into two gene pools (Eastern, Western), with secondary contact taking place between the two clusters in the central European, Italian, and Mediterranean region [42]. Our results are compatible with this broad study, according to which secondary contact between the two clusters probably took place in the Czech territory. Thus, low genetic differentiation in our tested yew populations is reasonable, a finding that was also observed by the authors of [42] in the Czech Republic or those of [41] in Great Britain. In Poland, the four Polish T. baccata populations, which are located close to the Czech borders, had a lower 
level of differentiation $\left(F_{\mathrm{ST}}=0.094\right)$ compared to the results of all of the tested Polish populations [43]. On the contrary, slightly higher genetic variability and higher pairwise differentiation than those shown in our results were reported in the Iberian Peninsula $\left(F_{\mathrm{ST}}=0.129\right)$ [45], in the Western Mediterranean Basin $\left(F_{\mathrm{ST}}=0.155\right)$ [40], and in Norway $\left(F_{\mathrm{ST}}=0.166\right)$ [46], which is compatible with strong fragmentation and inbreeding, declining towards the periphery of this species distributional range.

According to the STRUCTURE analysis, most populations were assigned to a specific gene pool (Figure $4 \mathrm{~b}$, for $K=4$ ), with a weak admixture in the TS_L unit. However, at lower hierarchy levels ( $K=2$, the optimum number of groups), relationships with other populations were also observed, especially between the TS_B and TS_L populations.

\subsection{Implications for Conservation}

To conserve endangered and threatened species, it is necessary to maintain their contributions to the overall genetic diversity. The populations of forest trees should be large and genetically diverse and should have no inbreeding depression, which inhibits population growth. Knowledge of the geographical patterns that are connected with genetic variation is also essential for designing efficient conservation management strategies. Our study detected sufficiently high genetic diversity in the tested populations and lower to moderate levels of genetic differentiation among them compared with other yew populations in Europe. However, the $F_{\mathrm{ST}}$ values were still higher than, for example, those of Picea abies or Fagus sylvatica in the Czech Republic [14,47].

Established seed orchards can be a useful safeguard against the loss of genetic diversity in the remaining scattered native population. This will allow the genetic diversity of the seedlings used to augment the local population. Since the TS_L unit shares high levels of genetic diversity with our tested T. baccata populations (TS_J, TS_M, and TS_B), we suggest not including any of these populations in the TS_L unit to prevent undesirable contamination (introgression). Multiplying the local subpopulation as much as possible (taking advantage of SO) is the preferred first step to increasing the genetic diversity of this species and only allowing interbreeding with neighbouring genetic resources that they encounter naturally.

Author Contributions: Conceptualization and methodology, M.K., P.N. and P.M; funding acquisition and project administration, P.N. and P.M.; plant material preparation, P.N. and M.K.; data curation, M.K., P.M. and H.C.; experiments and data analysis, M.K., P.N., H.C. and P.M.; writing-original draft, M.K.; writing-review and editing, M.K., P.N., H.C. and P.M. All authors have read and agreed to the published version of the manuscript.

Funding: This research was supported by grants from the Ministry of Agriculture of the Czech Republic (No. NAZV QK1810129), and Institutional Support (MZE-RO0118).

Institutional Review Board Statement: Not applicable.

Informed Consent Statement: Not applicable.

Data Availability Statement: Original data presented in the study are included in the main text, and further inquiries can be directed to the corresponding author.

Acknowledgments: The authors would like to thank Alexandr Hrozek from PLA Lužické Mountains Administration for collaboration on the research activities.

Conflicts of Interest: The authors declare no conflict of interest.

\section{References}

1. Sisak, L.; Riedl, M.; Dudik, R. Non-market non-timber forest products in the Czech Republic-Their socio-economic effects and trends in forest land use. Land Use Policy 2016, 50, 390-398. [CrossRef]

2. Sarli, S.; Ghasemi, N. Optimization of biosynthesized Zn nanoparticles by poisonous Taxus baccata leaves extract and evaluation of their effect on the bacterias and MCF-7 cancer cells. Eurasian Chem. Commun. 2020, 2, 302-318. [CrossRef]

3. Úradníček, L.; Čáp, J.; Jelínek, B.; Koutecký, T.; Maděra, P.; Řepka, R.; Tichá, S.; Vahalík, P. Červená Kniha Dřevin České Republiky; Lesnická Práce: Kostelec nad Černými Lesy, Czech Republic, 2017; ISBN 80-7458-098-9. 
4. Iszkuło, G.; Didukh, Y.; Giertych, M.J.; Jasińska, A.K.; Sobierajska, K.; Szmyt, J. Weak competitive ability may explain decline of Taxus baccata. Ann. For. Sci. 2012, 69, 705-712. [CrossRef]

5. Grulich, V.; Chobot, K. Červený seznam ohrožených druhů České republiky. Cévnaté rostliny. Př́roda 2017, 35, 1-178.

6. Thomas, P.A.; Polwart, A. Taxus baccata L. J. Ecol. 2003, 91, 489-524. [CrossRef]

7. Farris, E.; Filigheddu, R. Effects of Browsing in Relation to Vegetation Cover on Common Yew (Taxus baccata L.) Recruitment in Mediterranean Environments. Plant Ecol. 2008, 199, 309-318. [CrossRef]

8. Garbarino, M.; Weisberg, P.J.; Bagnara, L.; Urbinati, C. Sex-related spatial segregation along environmental gradients in the dioecious conifer, Taxus baccata. For. Ecol. Manag. 2015, 358, 122-129. [CrossRef]

9. Young, A.; Boyle, T.; Brown, T. The population genetic consequences of habitat fragmentation for plants. Trends Ecol. Evol. 1996, 11, 413-418. [CrossRef]

10. Frankham, R.; Ballou, J.D.; Eldridge, M.D.B.; Lacy, R.C.; Ralls, K.; Dudash, M.R.; Fenster, C.B. Predicting the Probability of Outbreeding Depression. Conserv. Biol. 2011, 25, 465-475. [CrossRef]

11. Miao, Y.-C.; Su, J.-R.; Zhang, Z.-J.; Lang, X.-D.; Liu, W.-D.; Li, S.-F. Microsatellite markers indicate genetic differences between cultivated and natural populations of endangered Taxus yunnanensis. Bot. J. Linn. Soc. 2015, 177, 450-461. [CrossRef]

12. Novotný, P.; Tomec, J.; Fulín, M.; Čáp, J.; Dostál, J.; Hrozek, A.; Hrozková, L.; Skaloš, J. Changes in the development of highly endangered common yew (Taxus Baccata L.) population in the Lužické Hory (Lusatian Mountains) after 20 years of intensified proteciton (1999-2019). Zprávy Lesn. Výzk. 2020, 65, 135-145.

13. Novotný, P.; Hrozek, A. Proposing of methodology for common yew (Taxus baccata L.) genetic resources conservation and reproduction in the protected landscape area Lužické Mts. Zprávy Lesn. Výzk. 2010, 55, 273-281. [CrossRef]

14. Máchová, P.; Trčková, O.; Cvrčková, H. Use of Nuclear Microsatellite Loci for Evaluating Genetic Diversity of Selected Populations of Picea abies (L.) Karsten in the Czech Republic. Forests 2018, 9, 92. [CrossRef]

15. Bínová, Z.; Korecký, J.; Dvořák, J.; Bílý, J.; Zádrapová, D.; Jansa, V.; Lstibůrek, M. Genetic Structure of Norway Spruce Ecotypes Studied by SSR Markers. Forests 2020, 11, 110. [CrossRef]

16. Mei, L.; Wen, X.; Fan, F.; Yang, Z.; Xie, W.; Hong, Y. Genetic diversity and population structure of masson pine (Pinus massoniana Lamb.) superior clones in South China as revealed by EST-SSR markers. Genet. Resour. Crop Evol. 2021, 68, 1987-2002. [CrossRef]

17. Mason, A.S. SSR Genotyping. In Plant Genotyping: Methods and Protocols; Batley, J., Ed.; Methods in Molecular Biology; Springer: New York, NY, USA, 2015; pp. 77-89. ISBN 978-1-4939-1966-6.

18. Winter, P.; Kahl, G. Molecular marker technologies for plant improvement. World J. Microbiol. Biotechnol. 1995, 11, 438-448. [CrossRef] [PubMed]

19. Kalia, R.K.; Rai, M.K.; Kalia, S.; Singh, R.; Dhawan, A.K. Microsatellite markers: An overview of the recent progress in plants. Euphytica 2011, 177, 309-334. [CrossRef]

20. Dubreuil, M.; Riba, M.; González-Martínez, S.C.; Vendramin, G.G.; Sebastiani, F.; Mayol, M. Genetic effects of chronic habitat fragmentation revisited: Strong genetic structure in a temperate tree, Taxus baccata (Taxaceae), with great dispersal capability. Am. J. Bot. 2010, 97, 303-310. [CrossRef]

21. Zatloukal, V.; Holá, Š.; Kačmar, M. European yew (Taxus baccata) in the Czech Republic Inventory 2007-2012; Folia Forestalia Bohemica, 1st ed.; Lesnická Práce: Kostelec nad Černými Lesy, Czech Republic, 2013; ISBN 978-80-7458-042-0.

22. Chybicki, I.J.; Oleksa, A.; Burczyk, J. Increased inbreeding and strong kinship structure in Taxus baccata estimated from both AFLP and SSR data. Heredity 2011, 107, 589-600. [CrossRef]

23. Dubreuil, M.; Sebastiani, F.; Mayol, M.; González-Martínez, S.C.; Riba, M.; Vendramin, G.G. Isolation and characterization of polymorphic nuclear microsatellite loci in Taxus baccata L. Conserv. Genet. 2008, 9, 1665-1668. [CrossRef]

24. Guichoux, E.; Lagache, L.; Wagner, S.; Chaumeil, P.; Léger, P.; Lepais, O.; Lepoittevin, C.; Malausa, T.; Revardel, E.; Salin, F.; et al. Current trends in microsatellite genotyping. Mol. Ecol. Resour. 2011, 11, 591-611. [CrossRef]

25. Chapuis, M.-P.; Estoup, A. Microsatellite null alleles and estimation of population differentiation. Mol. Biol. Evol. 2007, 24, 621-631. [CrossRef]

26. Peakall, R.; Smouse, P.E. GenAlEx 6.5: Genetic analysis in Excel. Population genetic software for teaching and research-An update. Bioinformatics 2012, 28, 2537-2539. [CrossRef] [PubMed]

27. Pritchard, J.K.; Stephens, M.; Donnelly, P. Inference of population structure using multilocus genotype data. Genetics 2000, 155, 945-959. [CrossRef]

28. Falush, D.; Stephens, M.; Pritchard, J.K. Inference of population structure using multilocus genotype data: Linked loci and correlated allele frequencies. Genetics 2003, 164, 1567-1587. [CrossRef]

29. Hubisz, M.J.; Falush, D.; Stephens, M.; Pritchard, J.K. Inferring weak population structure with the assistance of sample group information. Mol. Ecol. Resour. 2009, 9, 1322-1332. [CrossRef] [PubMed]

30. Alberto, F.; Niort, J.; Derory, J.; Lepais, O.; Vitalis, R.; Galop, D.; Kremer, A. Population differentiation of sessile oak at the altitudinal front of migration in the French Pyrenees. Mol. Ecol. 2010, 19, 2626-2639. [CrossRef]

31. Earl, D.A.; vonHoldt, B.M. STRUCTURE HARVESTER: A website and program for visualizing STRUCTURE output and implementing the Evanno method. Conserv. Genet. Resour. 2012, 4, 359-361. [CrossRef]

32. Nei, M. Genetic Distance between Populations. Am. Nat. 1972, 106, 283-292. [CrossRef] 
33. Chapuis, M.-P.; Lecoq, M.; Michalakis, Y.; Loiseau, A.; Sword, G.A.; Piry, S.; Estoup, A. Do outbreaks affect genetic population structure? A worldwide survey in Locusta migratoria, a pest plagued by microsatellite null alleles. Mol. Ecol. 2008, 17, 3640-3653. [CrossRef]

34. Wright, S. The Interpretation of Population Structure by F-Statistics with Special Regard to Systems of Mating. Evolution 1965, 19, 395-420. [CrossRef]

35. Jianping, H.; Zhang, W.; Cao, H.; Chen, S.; Wang, Y. Genetic diversity and biogeography of the traditional Chinese medicine, Gardenia jasminoides, based on AFLP markers. Biochem. Syst. Ecol. 2007, 35, 138-145. [CrossRef]

36. Aguinagalde, I.; Hampe, A.; Mohanty, A.; Martín, J.P.; Duminil, J.; Petit, R.J. Effects of Life-History Traits and Species Distribution on Genetic Structure at Maternally Inherited Markers in European Trees and Shrubs. J. Biogeogr. 2005, 32, 329-339. [CrossRef]

37. Chybicki, I.J.; Oleksa, A. Seed and pollen gene dispersal in Taxus baccata, a dioecious conifer in the face of strong population fragmentation. Ann. Bot. 2018, 122, 409-421. [CrossRef]

38. Guo, B.; Hao, X.; Han, L.; Zhai, Y.; Zhou, S.; Chen, S.; Ren, D.; An, X. Unraveling the genetic diversity and structure of Quercus liaotungensis population through analysis of microsatellite markers. PeerJ 2021, 9, e10922. [CrossRef]

39. Ahn, J.-Y.; Lee, J.-W.; Hong, K.-N. Genetic Diversity and Structure of Pinus densiflora Siebold \& Zucc. Populations in Republic of Korea Based on Microsatellite Markers. Forests 2021, 12, 750. [CrossRef]

40. González-Martínez, S.C.; Dubreuil, M.; Riba, M.; Vendramin, G.G.; Sebastiani, F.; Mayol, M. Spatial genetic structure of Taxus baccata L. in the western Mediterranean Basin: Past and present limits to gene movement over a broad geographic scale. Mol. Phylogenet. Evol. 2010, 55, 805-815. [CrossRef]

41. Gargiulo, R.; Saubin, M.; Rizzuto, G.; West, B.; Fay, M.F.; Kallow, S.; Trivedi, C. Genetic diversity in British populations of Taxus baccata L.: Is the seedbank collection representative of the genetic variation in the wild? Biol. Conserv. 2019, 233, $289-297$. [CrossRef]

42. Mayol, M.; Riba, M.; González-Martínez, S.C.; Bagnoli, F.; de Beaulieu, J.-L.; Berganzo, E.; Burgarella, C.; Dubreuil, M.; Krajmerová, D.; Paule, L.; et al. Adapting through glacial cycles: Insights from a long-lived tree (Taxus baccata). New Phytol. 2015, 208, 973-986. [CrossRef] [PubMed]

43. Litkowiec, M.; Lewandowski, A.; Wachowiak, W. Genetic variation in Taxus baccata L.: A case study supporting Poland's protection and restoration program. For. Ecol. Manag. 2018, 409, 148-160. [CrossRef]

44. Nybom, H. Comparison of different nuclear DNA markers for estimating intraspecific genetic diversity in plants. Mol. Ecol. 2004, 13, 1143-1155. [CrossRef] [PubMed]

45. Maroso, F.; Vera, M.; Ferreiro, J.; Mayol, M.; Riba, M.; Ramil-Rego, P.; Martínez, P.; Bouza, C. Genetic diversity and structure of Taxus baccata from the Cantabrian-Atlantic area in northern Spain: A guide for conservation and management actions. For. Ecol. Manag. 2021, 482, 118844. [CrossRef]

46. Myking, T.; Vakkari, P.; Skrøppa, T. Genetic variation in northern marginal Taxus baccata L. populations. Implications for conservation. For. Int. J. For. Res. 2009, 82, 529-539. [CrossRef]

47. Cvrčková, H.; Máchová, P.; Poláková, L.; Trčková, O. Evaluation of the genetic diversity of selected Fagus sylvatica L. populations in the Czech Republic using nuclear microsatellites. J. For. Sci. 2017, 63, 53-61. [CrossRef] 